JMKSP (Jurnal Manajemen, Kepemimpinan, dan Supervisi Pendidikan) Volume 6 Issue 2 (2021) Page 188-199

ISSN 2614-8021 (Online) 2548-7094 (Print)

\title{
Standardization of Islamic Education in Religious Value Education Orientation
}

\section{Zainal Muhtar ${ }^{1}$, Yosal Iriantara ${ }^{2}$, Sri Handayani ${ }^{3}$, Wahyudin ${ }^{2}$, Maria Yudianti $^{2}$ \\ ${ }^{1}$ Universitas Pertahanan Republik Indonesia, ${ }^{2}$ Universitas Islam Nusantara, ${ }^{3}$ Sekolah Tinggi Pariwisata Bandung Corresponding Author E-mail: zainal_muhtar90@yahoo.co.id}

Received 14 August 2021; Revised 2 December 2021; Accepted 27 January 2022

Abstract: Education is part of the future investment. The goals of education at any time need to be revised and adapted to the demands of change. Government Regulation Number 32 of 2013 concerning National Education Standards (SNP) provides direction on the need to develop and implement eight national education standards, namely: content standards, process standards, graduate competency standards, educators and education personnel standards, facilities and infrastructure standards, management standards, financing standards, and educational assessment standards. This study aims to describe the standardization of Islamic education on the orientation of religious values education. The National Education Standards have been implemented in accordance with the scope of their responsibilities to date. Even so, there are still pros and cons in the SNP policy, one of the reasons for the pro group is that standardization serves as a guide for teachers in making global changes, while those who oppose explain that standardization of education is heavily influenced by business and political decisions.

Keyword: Standardization, Education, Religious, Philosophy, Sociology 


\section{Introduction}

Education is part of future investment, public investment as well as state investment in the context of advancing and educating the nation's life (Murtiningsih, 2017). So, in order to achieve these goals, education is always directed to answer several things related to national and ummah issues. In this case, when we relate to Islamic education today, how Islamic education is able to answer Islamic problems which are often faced with cases of violence in the name of religion, tolerance between religious communities and the creation of a conducive situation in carrying out religious teachings (Syar'i, Ahmad, 2017).

In the world of education, there is always a development of the various components that make up education itself. Therefore, education is a purposeful process. Every purposeful process certainly has a measure of where our educational journey is in achieving that goal (Ahmad, M, 2021). This means that the goals of education at any time need to be revised and adapted to the demands of change. Where there is a considerable influence from the continued increase in world technology, which has an impact on education, then there are demands for changes both in terms of content and delivery. In this regard, the government has made various arrangements in the standardization system of education, as stated in Law Number 20 of 2003 concerning the National Education System, where the implementation is translated into a number of regulations, including Government Regulation Number 19 of 2005 which is now replaced with Regulation Government Number 32 of 2013 concerning National Education Standards (SNP) (Surakhmad, etc., 2017). This Government Regulation provides direction on the need to develop and implement eight national education standards, namely: content standards, process standards, graduate competency standards, educators and education personnel standards, facilities and infrastructure standards, management standards, financing standards, and education assessment standards.

\section{Methods}

This research uses descriptive qualitative research methods. According to Bogdan and Taylor, as quoted by Lexy J. Moleong (2018), qualitative research is a research that produces descriptive data in the form of written or spoken words from people and observed behavior. Meanwhile, descriptive research is a form of research aimed at describing or describing existing phenomena, both natural phenomena and human engineering. The descriptive method was chosen because the research carried out was related to ongoing events and with regard to current 
conditions. The data collection technique used in this study is a literature study. Literature review is a method used to gather data or sources related to the topic raised in a study. Literature studies can be obtained from sharing sources in journals, books, documentation, the internet and libraries. Once the data is collected, the next process is to analyze the data. In providing interpretation of the data obtained, researchers use descriptive methods. Descriptive analysis technique is a research technique that includes the process of collecting data that has been collected and compiled and then analyzed so that clear research data is obtained (Surachmad, 1998). This method is suitable in this study because this study seeks to find a picture of standardization of islamic education in religious value education orientation.

\section{Results and Discussion}

Policy on National Education Standardization which has been regulated in Government Regulation no. 19 of 2005 regarding various standards that must be met in the education system, it can be seen that the development of education in Indonesia has been planned in a clear and directed manner. However, there are pros and cons to this policy.

\section{Pro about standardization policy}

In general, groups that believe in standardization of education will improve the learning process of students but with certain conditions. This group agrees on the existence of educational standardization if the standard meets the following requirements 1) the standards to be implemented reflect the policies or wisdom of parents and teachers. This means that standards are not determined from an institution outside of stakeholders, especially in education, namely parents and teachers; 2) the preparation and setting of content standards or curriculum must be done carefully. Its preparation must involve curriculum experts because the preparation of educational curricula has undergone various advances. The curriculum cannot be prepared by just anyone, by amateurs or politicians, but by specialists in curriculum so that the standards that have been determined get a clear and directed framework in the curriculum; 3) the standards that have been determined should be implemented by professional teachers; 4) academic progress at school cannot be solely through final tests or final exams; 5) standards must provide equal opportunities for all students. If the standard discriminates against 
students, then the standard is a barbaric rape of the same human nature (Mulyasa, E, 2015).

\section{Cons About Standardization Policy}

Nowadays the standardization of education is heavily influenced by business and political decisions. This is evident when the change of a leader will also experience changes in setting policies, for example the change in PP No. 19 of 2005 was changed to PP No. 32 of 2013 in accordance with the changing of leadership milestones in policy holders to the change of the curriculum (Amri, A. (2017).

Standardization has determined a goal that lies outside the educational process itself. Moreover, standards are determined by a bureaucracy that does not know what is going on in practical education in schools. In addition, the standardization of education regulated in PP no 19 of 2005 now PP no 32 of 2013 on national education standards emphasizes the need for the education community to refer to the set of quality standards as a formal and standard reference in efforts to improve the quality of education. Although the basic concept of the provision is operationally still unclear. PP No. 19 of 2005, now PP No. 32 of 2013 provides minimum criteria for the applicable national education system. This means that each educational unit must at least meet these minimum standards in order to be assessed as quality. As a consequence, any educational unit that does not meet these standards is a substandard institution of low quality. So that this provides an understanding that discrimination and distinction will be created, while the initial goal of national education is to provide equality in education without any discrimination.

In addition to the reasons above, the group against the standardization of education also stated that the success of an education is not only seen from the final exam as a national evaluation material. However, in PP No. 32 of 2013 there was a change related to the national final exam that for elementary school levels, both SD and MI had been abolished.

Islamic education is a part of Islam itself, therefore Islamic education should not run away from the meaning of Islam which aims to seek the success of spiritual and material life. Therefore, the basis used in Islamic education is the arguments of the Qur'an and hadith which contain global or detailed information about Islamic education. In addition, other provisions are also used which in the history of Islamic education have been tested for their substance. Islamic education has two main orientations, namely first to serve Allah as khaliq and to 
understand himself as a caliph on earth. This orientation is useful for designing students' beliefs to remain framed in Islamic values and morality. Second, educate by understanding the nature of students, at this limit it is not only Islamic education material that is urgent but the learning methods and processes are also important. Keywords: Values, Basics, Islamic Religious Education Orientation.

Religious education is often identified as morality education. This is because the desired end result of diversity is being able to elevate the morality of its adherents and keep it away from traits that are disgraceful according to common standards for humans. Thus the mission of the most substantial religious education is to engineer humans to produce humans who have high morality. People who have higher religious education will certainly have higher morality. But what is thought is not always in accordance with the assumptions that develop. There is a negative thought that discredits that religious education is not entirely capable of elevating and engineering perfect morality, even more extreme is that religious education is often a trigger aspect for violence and war. If you look at it through the lens of what it is, then the anxiety will take place, but if it is understood objectively, then the assessment seems very subjective. Education in addition to providing directions for the future, actually has a dialectical relationship with social and community transformation.

Islam as a religion is the most prepared to face this transformation. Therefore, this paper tries to describe the basis and orientation of Islamic Religious Education, whether it is fundamentally and oriented to tolerate all forms of anxiety or is it just that anxiety does arise because of other aspects. Islamic Religious Education In Indonesian, religious education comes from two words, namely education and religion. The word education comes from the word "educating" given the prefix "pe" and the suffix "kan", which means deeds, ways, things. While the meaning of educating itself is to maintain and provide training (teaching or leadership) regarding morals and intelligence.

There are two starting points in the definition above, namely, morals and intelligence, morality is related to the behavior and attitude patterns of students, while intelligence is related to mastery of learning materials. Compare this understanding with the notion of education in the English word, namely education which comes from the Latin word "educare" which means to process, produce and develop, referring to the physical and material nature (Cahyono, etc., 2018).

In this part of the definition, it is seen that secularism is the domain of the scope of education in the West which only emphasizes intellectual intelligence 
and ignores other intelligences. Islam as a system of values and morals follows the flow of Allah's will contained in the two main axis sources of the Qur'an and hadith, so the value system or moral system that is used as a frame of reference becomes the main reference in the outward and spiritual behavior of each of its adherents. Therefore, by itself Islamic education must be based on the moral principles mentioned in the revelation and the texts that exist as a reference.

This related with what was stated by Abul 'Ala Maududi who stated that the Islamic moral system has perfect characteristics, namely that moral standards and goals are the pleasure of Allah SWT. Moral in Islam is comprehensive and regulates all aspects of human life, the system of life is based on the norms of benefit.

Islamic education by definition cannot escape from Islam itself as the moral basis and the whole building. Because of that, Islamic education basically regulates life and the process of human engineering to produce the humans expected by Islam. Thus, Islamic education in principle is an effort to instill awareness of the divinity of a student for worldly and hereafter interests. Islam which contains moral teachings, a lot of guidance regarding education, even in this case Islam can be said as a religion of education. Muhammad Quthub in his book says that in the Qur'an there seems to be a lot of demands regarding education, these demands have a certain influence on a person's soul, if someone has lived it and felt it will definitely have a way of behaving, thinking and feeling. He will be closer to truth and piety, will become a more sensitive and more humane person (Novita, M, etc., 2021).

The authors differ in defining the meaning of Islamic Education in Islam, but substantially the whole definition includes what has been described above, for example (1) Umar Muhammad Al-Taumy Al-Syaebani, said that Islamic education is an attempt to change individual behavior in life. his personality, society, and life with the natural surroundings, through the educational process, these changes are based on Islamic values; (2) Zakiah Daradjat said Islamic Religious Education is an effort to foster and nurture students so that they can always understand the teachings of Islam as a whole, live the goals of Islamic Religious Education and can practice it as a way of life (3) Tayar Yusuf said that Islamic Religious Education as a aware of the older generation to transfer experience, knowledge, skills and skills to the younger generation so that later they become human beings who fear Allah SWT; and (4) A. Tafsir, said that Islamic Religious Education is guidance given by someone to someone so that he 
or she develops optimally in accordance with Islamic teachings, Meanwhile, according to the Director General of Islamic Religious Institutional Development, formulating the meaning of PAI is a conscious effort to prepare students to believe, understand, living and practicing Islam through guidance, teaching, and training activities, taking into account the demands to respect other religions in inter-religious harmony to realize national unity.

The latter is a definition that includes the terminology and operational definitions of the meaning of Islamic education itself. Basics of Islamic Education In Arabic there are at least three words that are often used to describe the meaning of religious education, namely the words tarbiyah, ta'lim, and ta'dib. These three concepts are pure concepts that have developed in the Islamic world and are still widely discussed today.

From the three concepts that developed, there were various opinions. There are writers who say one word is wider than another, others say the opposite. For example, what Al-Atas said, quoted by Hasan Langgulung, who said that ata Ta'lim means teaching, while the word tarbiyah means education which is wider in scope than the word Ta'lim because some countries use the word tarbiyah more which means to maintain , defend, and so on instead of using the word Ta'lim". Zakiah Daradjat disagrees with the statement above, she says the verb "Rabba" comes from the word Tarbiyah which indicates the meaning of education has been used since the time of the Prophet, while the word Ta'lim comes from the verb Allama which means teaching.

As for the basis of the existence of Islamic education a. Religious basis Religious basis is the basis that comes from Islamic teachings, verses that show the command to educate 1) Q.S. An-Nahl verse 125, thats meaning: "Call (humans) to the way of your Lord with wisdom and good lessons and refute them in a good way. Verily, your Lord knows best who has strayed from His path and it is He who knows better those who are guided."

Uridical Legal Basis, including: 1) Ideal basis, namely the state philosophy: Pancasila, the first principle of divinity in the One and Only God. 2) Constitutional Basis: UUD 1945, Chapter XI Article 29 paragraph 1 which reads: Paragraph 1) The state is based on the belief in the one and only God. Paragraph 2) The state guarantees the independence of every citizen to embrace their own religion and worship according to their religion and belief. 3) Operational basis; according to the curriculum used by the school. c. Basic Social Psychologist Every human being in this life, always needs a grip on life called religion, they 
feel that in their soul there is a feeling that acknowledges the existence of the Almighty Substance. They will feel calm and at ease if they can approach and serve the Almighty

Because of that, humans will try to get closer to God, it's just that the way they serve and get closer varies according to their religion, which is why for Muslims it is necessary to study Islamic Religious Education in schools, because school is one of the means that influence one's psyche. Islamic Education Orientation What characterizes Islam is an adaptive and tolerant attitude towards human social and cultural developments. This attitude has confirmed Islam as a religion that is ready to face all the changes of time accompanied by the development and advancement of technology and information. Because of that there is a kind of belief from all those who embrace Islam that this religion is a religion that is al-Islam shalih li kuli Zaman wa eat (a religion that is appropriate at all times and in every place).

The adaptive and tolerant attitude which is often referred to as Islamic universalism is often a fundamental question for Islam itself and more specifically for Islamic Religious Education, namely the question of whether Islam has its own concept of Islamic Religious Education itself. And this question has been asked by Syed Hossen Naser who thinks that Islam only adapts and even adopts educational systems and institutions that come from the socio-cultural and community environment it encounters. If this statement is taken literally, it will justify the assumption that Islamic religious education is education that does not have a clear orientation, because it is elastic and has multiple interpretations. However, if it is understood universally, then in fact the main orientation of Islamic education is universalism itself. The existence of an adaptive and accommodative attitude itself confirms the relevance and at the same time the significance of Islamic values for development.

In the history of the development of Islamic education, Islam has played its role not only in the aspect of religious rituals, but in other fields the situation has grown along with the growth of Muslims themselves. In the early days there was no rejection from any party about the need for knowledge for Muslims. And this understanding then developed rapidly in Islamic dynasties marked by the birth of Islamic educational institutions, such as observatories, maktab-maktab, and kuttab-kuttab which marked the glory of Islam. Operationally, Islamic education is oriented to two things at once: educating humans to become servants of Allah 
whose task is to serve Allah ('abd Allah) and present oneself as a human being on earth (khalfah fialrd).

Directorate General of Islamic Religious Institutions, Familiarizing Religious Traditions not with an orientation to elevate a human orientation but rather a political and economic orientation. Faith is the most important element of all human actions. Belief is something that can move the entire human potential to act. Belief is the first orientation in humans that he uses in justifying all his actions. Therefore, Jenny Teichman in her work Social Ethic: A Student's Guide says that all actions and the way people act are influenced by beliefs about what is good and bad.

Educating humans in order to develop the basic completeness and natural potential of students optimally to reach intellectual maturity and emotional maturity. In this orientation will suggest a proportional and proportional operational design. In the sense that the ideal conception of Islamic Religious Education must be implemented within the framework of professional management starting from its planning, strategy, method, and evaluation.

Education as it is believed is an effort to meet the needs of the child, satisfy his interests, respect his personality, and always give him the opportunity to develop well. After that the child is able to adapt to a good environment. To achieve that goal, it is not only good material that needs to be presented to students, but it is also necessary to present good methods and strategies so that the material can be internalized within students. Good material that is not accompanied by a good presentation will make the work in vain. The teacher is not the main factor because the main factor lies in the students, namely the extent to which students are able to present their skills, understanding and habits. Referring to the second orientation, namely the nature of students, what becomes substantial is that in Islamic Religious Education it is very necessary to understand students as a whole. Because every student must have a different nature.

This is in accordance with the expression that says that students are not like the teeth of a comb that are evenly distributed, but rather a complete figure who is independent and different from one another in various ways. For this reason, the presentation of Islamic education materials must be adapted to the very distinctive and unique character and personality of students. So far, the presentation of Islamic Religious Education material tends to ignore the nature of students, and always prioritizes material content and material content rather than processes and 
methodologies that prioritize human nature. Aspects of strengthening thinking (formalistic) have resulted in students becoming rigid and closed in social interactions. Constructive and innovative efforts simultaneously and continuously in the context of the success of Islamic Religious Education is an absolute musthave effort to find an epistemological framework and methodology of Islamic Religious Education that is relevant to change and development in order to distance itself from ending traditional and conventional sustainability.

\section{Conclusion}

The background of the National Education Standards Policy is Law No. 20 of 2003 concerning SISDIKNAS which then led to PP No. 19 of 2005 which is now replaced by PP No. 32 of 2013 concerning SNP. SNP is the minimum criteria regarding the education system throughout the jurisdiction of the unitary state of the Republic of Indonesia. Its function is as a basis for planning, implementing, and supervising education in the context of realizing quality national education. The scope includes: Graduate Competency Standards, Content Standards, Process Standards, Educators and Education Personnel Standards, Facilities and Infrastructure Standards, Management Standards, Financing Standards, and Educational Assessment Standards.

The SNP in the process has its own body, namely the National Education Standards Agency (BNSP) or an institution formed based on and mandated by the National Education System Law with the mission to develop, monitor the implementation, and evaluate the implementation of national education standards. BSN assesses that the implementation of the National Education Standards has been carried out in accordance with the scope of its responsibility to date. Even so, there are still pros and cons in the SNP policy, one of the reasons the pro group is that standardization serves as a guide for teachers in making global changes, while those who oppose explain that standardization of education is heavily influenced by business and political decisions.

\section{Acknowledgement}

Acknowledgments were extended to all who contributed to this research. Thank you to Rector Universitas Pertahanan Republik Indonesia, Universitas Islam Nusantara, and Sekolah Tinggi Pariwisata Bandung. Thank for the team JMKSP (Jurnal Manajemen, Kepemimpinan, and Supervisi Pendidikan) that given suggestion in peer review process. 


\section{References}

Ahmad, M. (2021). Academic Stress: How Extrinsic Motivation and Self-Efficacy Affect. JMKSP (Jurnal Manajemen, Kepemimpinan, dan Supervisi Pendidikan), 6(2), 164-180.

Amri, A. (2017). Peran Pemimpin dalam Memotivasi Pegawai Tata USAha (Studi pada Mts Negeri Koto Baru, Kabupaten Solok) [The Role of Leaders in Motivating Administrative Employees (Study at Mts Negeri Koto Baru, Solok Regency)].JMKSP (Jurnal Manajemen, Kepemimpinan, dan Supervisi Pendidikan), $1(2), 80-88$.

Cahyono, H., Suhono, S., \& Khumairo, A. (2018). Pendidikan Karakter Bagi

Pelaku Pedofilia (sebuah Strategi dalam Mengatasi Amoral) [Character Education for Pedophiles (a Strategy in Overcoming Immorality)]. JMKSP (Jurnal Manajemen, Kepemimpinan, dan Supervisi Pendidikan), 3(1), 1-19.

Murtiningsih, M., \& Lian, B. (2017). Proses pengambilan keputusan kepala sekolah terhadap peningkatan kinerja guru SMP [Principal's decisionmaking process on improving the performance of junior high school teachers]. JMKSP (Jurnal Manajemen, Kepemimpinan, dan Supervisi Pendidikan), 2(1), 87-96.

Moleong, L. J. (2018). Metodologi Penelitian Kualitatif [Qualitative Research Methodology]. PT Remaja Rosdakarya.

Mulyasa, E. (2015) Pengembangan dan Implemetasi Kurikulum 2013 [Curriculum 2013 Development and Implementation]. Bandung: Remaja Rosdakarya

Novita, M., Madyan, M., \& Sukatin, S. (2021). The Framework of Islamic Educational Management to Improve Quality of Graduates. JMKSP (Jurnal Manajemen, Kepemimpinan, dan Supervisi Pendidikan), 6(2), 309-317.

Peraturan Pemerintah RI No. 19 tahun 2005 [RI Government Regulation No. 19 year 2005].

Peraturan Pemerintah No. 19 Tahun 2005 [Government Regulation No. 19 of 2005]

Peraturan Pemerintah No. 32 tahun 2013 [Government Regulation No. 32 years 2013].

Surakhmad, W. (2017). Pendidikan Nasional Strategi dan Tragedi [National Education Strategy and Tragedy]. Jakarta: Kompas Media Nusantara

Surachmad, W. (1998). Metode Penelitian Ilmiah [Scientific Research Method]. Bandung: Trasito. 
Syar'i, Ahmad. (2017). Filsafat Pendidikan Islam [Islamic Education Philosophy]. Jakarta: Putaka Firdaus,

Tilaar, H.A.R. (2019). Standarisasi Pendidikan Nasional: Suatu Tinjauan Kritis [National Education Standardization: A Critical Review]. Jakarta: Rineka Cipta 